\title{
Beach volleyball athlete training trends of Russian-language scientific resources: a systematic review
}

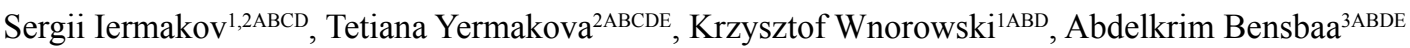 \\ ${ }^{1}$ Gdansk University of Physical Education and Sports, Gdansk, Poland \\ ${ }^{2}$ Kharkiv State Academy of Design and Arts, Kharkiv, Ukraine \\ ${ }^{3}$ Military Center of Sport Training, United Arab Emirates
}

Contribution of authors: A - Research design; B - Data collection; C - Statistical analysis; D - Preparation of the manuscript; E-Funds Collection.

\begin{abstract}
Background The inclusion of beach volleyball in the program of the Olympic Games gave some impetus to the and Study Aim development of scientific research on various problems of training athletes. Most of the research results are presented in journals included in the Web of Science Core Collection. However, the publication of research results in journals from national databases remains outside the scope of this database. The aim of this study is to systematically review the scientific literature on various beach volleyball issues in Russianlanguage scientific resources.

Material and The sources of information were the authoritative database Web of Science Core Collection, Russian Science Methods Citation Index, Scientific Electronic Library eLIBRARY.RU (Russia), National Repositary of Academic Texts (Ukraine). Data extraction from these databases was carried out using the keywords "volleyball" / "beach". A total of 1,875 documents were found for the keyword "volleyball". Of these, the keyword "beach" - 273 documents. Further analysis was carried out on 273 documents. The search query results were recorded in the form of tables and a special text file, which were processed in the VOSviewer 1.6.17 program.

Results The most significant and more popular subject categories, journals, authors, articles, keywords have been identified. The relationship between keywords and individual groups of publications has been established. A method for extracting data from the Scientific Electronic Library eLIBRARY.RU in a semiautomatic mode is presented. The trends in the development of beach volleyball in various aspects of the training of elite athletes and the sports reserve, the health-improving function of beach volleyball for youth are shown.

Conclusions Differences in the content of research between Russian-language and English-language resources are a good complement to each other. This fact may contribute to solving the problems of beach volleyball and international cooperation of researchers.

Keywords: bibliometric analysis, terms, youth, trends, sports selection, sports reserves, health.
\end{abstract}

\section{Introduction}

Competitiveness in beach volleyball competitions forces coaches and athletes to look for new approaches to organizing and conducting the training process. A certain role in this search is assigned to scientific research, the results of which are usually reflected in journals from databases. The most authoritative is the Web of Science Core Collection (WoS). WoS covers a fairly large number of publications in various subject categories. The vast majority of publications in the database are presented in English. It can be assumed that the leading countries in beach volleyball have their own publications in the national language. Such resources may contain quality scientific research that is not available to most beach volleyball professionals. In this context, the search for information in national languages is of great importance. The analysis of such publications can be presented in the English-language journals of the WoS database. This approach is quite justified - it significantly expands the audience of users. Russia and Ukraine are among the leaders in beach volleyball. An analysis of resources in the national languages of these countries can provide new

\footnotetext{
(c) Sergii lermakov, Tetiana Yermakova, Krzysztof Wnorowski,

Abdelkrim Bensbaa, 2021

doi:10.15561/20755279.2021.0508
}

insights into beach volleyball trends.

The global trends in the development of beach volleyball are reflected in the studies, the results of which are presented in the journals of the WoS database. Dyreson [1] believes that modern beach volleyball should be viewed as a global phenomenon with transnational origins. Another study [2] reported an increase in the popularity of beach volleyball since its inclusion in the Olympic Games. The authors propose creating a database that can be used to identify trends for training stages. Prospects for creating models of behavior of athletes and areas of technical training are presented in the studies of Gea et al. [3] and Zemkova et al. [4]. Similar opinions about the need to identify promising areas of research can be traced in the works of other authors [5-7]: model of orientation towards success; forms of partnership between two athletes that will help in achieving success; approaches to creating a familiar training environment for athletes. Research by Giatsis et al. [8] and Medeiros et al. [9] are devoted to the technical training of athletes in beach volleyball. The authors believe that serve (standing serve, jump serve, float jump serve) and spike have different performance profiles based on technique, player role, and age. Other studies consider: tactics of team actions [10]; 
attack tactics [11, 12]; competitive activity [13, 14]. In general, the WoS database presents a fairly wide range of research areas in beach volleyball.

Survey publications in the WoS database give a good idea of the trends in beach volleyball development. Systematic review by Jimenez-Olmedo et al. [15] is devoted to the analysis of publications on injuries and pathologies in beach volleyball. The authors distinguish three areas: studies of injuries of the shoulder, scapula, knee and foot; study of the incidence, prevalence and frequency of injuries; infections; the impact of injuryrelated training programs. Monteleone et al. [16] observed two cases of severe deltoid muscle atrophy not caused by any trauma. Cheron et al. [17] presents an analysis of publications on various injuries in beach volleyball. The authors highlight injuries associated with overload, cumulative injuries, injuries of the musculoskeletal system. In a study by Ahmad et al. [18] is identified a tendency towards an increase in the proportion of athletes with cartilage damage with age. Closs et al. [19] presented estimates of the effectiveness of combined methods for rapid recovery. Other studies on trauma and directions for recovery include reviews by Doyscher et al. [20], Marques [21]. Systematic reviews of other beach volleyball issues in the WoS database have not been found. There is a predominant focus of research on solving the problems of injuries and recovery from injuries.

The Russian-language segment of publications in the Web of Science database (RSCI - Russian Science Citation Index) on beach volleyball is represented by 5 publications on the following topics: classes with students using beach volleyball [22-24]; preparation of national teams for international competitions [25-26]. For the formation of trends in solving the problems of beach volleyball, 5 publications are clearly not enough. Therefore, it makes sense to consider other resources: Scientific Electronic Library eLIBRARY.RU (SEL, Russia) [27]; National Repositary of Academic Texts (Ukraine) [28].

SEL research includes several lines of research.

Technical training.

Serve. It is presented the following results of problem solving: improvement of technique and accuracy of serve [29]; increasing the speed in attacking actions and serves [30]; increasing the efficiency of serves [31, 32]. The studies reviewed have substantiated: the effectiveness of psychomotor control; main selection criteria; indicators of efficiency and effectiveness of competitive actions.

Attacking strike. The studies examined: the effectiveness of an attacking strike in various situations [29]; approaches to improving the attacking strike technique [33]; the effectiveness and information content of the parameters of the attacking strike technique [31, $32,34]$. The studies reviewed revealed: new tactical patterns of behavior of athletes; directions for improving technology at the initial stages of training; strengths and weaknesses of the preparedness of the leaders of Russian beach volleyball; model parameters of the power variant of the attacking strike.
Digging of the ball from the serve. Research topics are as follows: the influence of the method of digging the serve on the effectiveness of the digging [29] and on the passing the ball for hitting [35]; the effectiveness of competitive activity [31] and the dynamics of parameters of serving [32]. In the studies reviewed, the following are determined: directions of pedagogical control; quantitative and qualitative indicators of competitive activity.

Blocking. The problems of evaluating the effectiveness of blocking [31] and the dynamics of the studied parameters [32] are considered. The authors note the importance of blocking in conditions of confrontation between athletes.

Defence. The main tactical defence systems are considered [29]. The priority technical elements of the game in defence were revealed [35]. Information about the effectiveness of the game in defence is given [31]. Criteria for the effectiveness of playing actions in defence [36] and the effectiveness of ball receptions in defence [32] have been substantiated. The authors lead to the conclusion that defensive actions are closely related to the tactics and level of interaction of athletes in the team.

Tactical training. The main tactical defence systems [29] and the main role of tactical training [37] are considered. A pedagogical program for assessing individual technical and tactical actions is presented [36]. The results of changes in the level of technical and tactical readiness are shown [38]. The authors note that athletes often have to change tactical patterns of interaction in order to achieve success.

Physical training. The directions of increasing the level of physical fitness of athletes [39-43] and the realization of physical capabilities of athletes [37] are shown. The level of development of specific physical qualities $[44,45]$ and physical conditions of athletes [46-48] was assessed. The directions of improvement of special physical qualities of athletes are considered [35, 49]. The importance of pedagogical control of the current physical condition of athletes is noted [50-52]. In the studies reviewed, it is noted that the level of physical fitness of athletes is a criterion for success in extreme environmental conditions (wind, sand, sun and other natural factors).

Competitive activity. The dynamics of indicators of efficiency and effectiveness of competitive actions of the strongest Russian players is presented [32]. The impact on athletes of various stress factors caused by competitive activity has been considered [37]. The psychophysiological features of the athletes' competitive potential have been identified [53]. The quantitative and qualitative indicators of competitive activity are considered [35]. Pedagogical observation and analysis of the training-competitive process were carried out $[31,36,54,55]$. The stages of pre-competitive training are highlighted [56]. The criteria of readiness for competitive activity of the players of the Russian national team are shown [57]. The methods of pre-competitive training [58], planning of training and competitive loads [42] and the peculiarities of the period of preparation for the return competition [59] are presented. The estimation of adaptation in the period of 
precompetitive training is given [52]. A rational ratio of training and competitive loads was revealed [60]. In the studies reviewed, it is noted that success largely depends on the rational planning of pre-competitive training, criteria for the readiness of athletes.

The structure and content of the training process. Optimal volumes, orientation [61] and intensity of physical activity are proposed [49, 58, 62]. Estimates of the influence of training loads on morphological and functional indicators are presented [63]. The directions of optimization of individual training loads $[64,65]$ and a rational ratio of training and competitive loads [60] are proposed. Other studies recommend approaches to the rational construction and planning of training loads [42]. Pedagogical control of physical activity is of great importance [54]. For athletes of national teams, recommendations have been developed on training loads to prepare for the Olympic Games [29, 32]. Kostyukovet al. recommends taking into account the external and internal motivation for training [56]. Dashaev et al. focuses on the aspects of building psychological training in the training process [37]. The importance of using special equipment in the training of athletes is noted by Sukhanov et al. [66]. In the studies reviewed, the authors argue that the optimal ratio of the leading factors (volume, focus and intensity of physical activity) allows achieving success in competitive activity. Equally important is the criteria for the psychological readiness of athletes to overcome extreme factors.

Biomechanical aspects of movement techniques. The biomechanical features of the combined effects of movements are considered in the study by Pogrebnoy et al. [29]. The analysis of the biomechanical components of the jump was reviewed by Goncharuk [67]. Buczynski et al. [68] consider the biomechanical analysis of the attacking spike as an important aspect of the training of athletes. In other studies, model biomechanical characteristics of athletes' movement techniques have been considered $[33,69]$. The authors note that consideration of the biomechanical aspects of movement technique allows athletes to achieve the desired results and perform movements in an optimal mode with minimal energy consumption.

Beach volleyball as a recreational activity. In a study by Bich et al. [70] considered the theoretical aspects of the implementation of health and fitness practices. Kondrakovet al. [22] recommends using a functional model of student's recreational physical culture. The directions of popularization of beach volleyball in the context of adaptive physical culture and adaptive motor recreation are highlighted in the work of Kryvinia et al. [71]. Other studies recommend the use of beach volleyball in wellness activities $[64,72]$. In the studies reviewed, the authors argue that beach volleyball is a good tool for outdoor activities and a healthy lifestyle for young people.

The distribution of the number of publications by countries in the WoS database for the period 2010-2021 shows the presence of only two publications from Ukraine and Russia. This points to the need to analyze beach volleyball scientific resources in national languages.

Analysis of publications in the WoS database shows that the main attention was paid to the research of trauma and methods of rehabilitation, individual and team psychological training. Somewhat less attention is paid to the technical and tactical training of athletes.

The analysis of Russian-language publications indicates that there is research on all the main aspects of training athletes in beach volleyball. The greatest attention was paid to the research of technical and tactical training and competitive activity, the training of national teams, the health-improving orientation of beach volleyball lessons. We found no studies of sports injuries and rehabilitation aspects of the training process.

Such an analysis allows us to assert that there are significant differences in the content of the studies that are presented in the WoS database and in Russian-language scientific resources.

The aim of the research is a systematic review of scientific literature on various problems of beach volleyball in Russian-language scientific resources.

\section{Methodology}

Sources of data.

To analyze the information, we used the following databases:

- Web of Science Core Collection (WoS);

-Web of Science (RSCI - Russian Science Citation Index);

- Scientific Electronic Library eLIBRARY.RU (Russia) [27].

- National Repositary of Academic Texts (Ukraine) [28].

The main criterion for choosing databases is the quality of information sources. Web of Science includes RSCI ( 887 best Russian journals, 16.06.2021). Scientific Electronic Library eLIBRARY.RU includes 5213 Russian journals. All journals in these databases have passed preliminary assessment. Periodically, logs that do not meet the established criteria are excluded from these databases.

The databases were searched for the keywords "volleyball" / "beach".

Search results show:

- Web of Science Core Collection (period 2010-2021, keyword "beach volleyball") - 181 articles.

- RSCI - 152 articles for the keyword "volleyball". Of these - 5 articles on the keyword "beach".

- SEL - 1541 articles on the keyword "volleyball". Of these - 87 articles on the keyword "beach".

- National Repositary of Academic Texts (Ukraine) 32 documents on the keyword "volleyball". Of these, 1 document (2004) on the keyword "beach".

Research Design

Inclusion and exclusion criteria.

The main requirement for information sources is quality. Therefore, we chose the authoritative Web of Science Core Collection database. The search depth in this database was limited to 10 years. This is due to the fact that over the past 10 years, the technique, tactics and other components of beach volleyball have undergone 
great changes. Therefore, earlier studies will not play an important role in identifying trends in beach volleyball. Authors who have the "total link strength" criterion (criterion in the VOSviewer program) equal to zero were excluded from the analysis of the SEL database (Russia). Also, publications that do not have annotations were excluded. These publications are for informational purposes only and are of little value to our research. Publications in other languages were excluded from the RSCI search. The National Repositary of Academic Texts (Ukraine) was also excluded from the search. A search in this database showed the presence of only one document from 2004 (thesis abstract in Russian).

The Web of Science database includes the Russian Science Citation Index. RSCI is formed from the best Russian journals, which are presented in the Scientific Electronic Library collection eLIBRARY.RU (Russia). These journals were selected by a group of reputable Russian experts.

From these two databases, data related to publications in the field of beach volleyball were extracted. Most of the publications before 2010 were excluded from the review because their content has lost its relevance.

First step. Revealing global trends in beach volleyball research. The search query was carried out on the Web of Science Core Collection (181 articles, period 2010-2021, the keyword "beach volleyball." Data set was generated (section Export / Other File Formats / Record Content: - Full Record and Cited References / File Format - Plain Text) and saved as a text file. This file was used for bibliometric analysis.

The search made it possible to highlight the TOP-10 of the most important subject categories, journals and authors (Table 1).

Second phase. Identifying trends in beach volleyball research in Russian-language sources.

A search was carried out in the Russian Science Citation Index base. A total of 5 articles were found with the keywords "beach volleyball". The search results were included in the data set generated from the Scientific Electronic Library database.

The search query was conducted on Scientific Electronic Library (SEL). SEL does not make it possible to form a search data set. Therefore, we have formed a data set in which each article is represented by key data (Table 2). The textual part of this dataset has been translated into English. The table is an abbreviated version of the WoS search results. Out of more than 30 fields in the WoS array, we have left only 7 fields. This is due to the great complexity of extracting information from SEL. The generated data set was used for bibliometric analysis.

Table 2. Data collection model for analysing information from SEL.

\begin{tabular}{ll}
\hline Tag & Title \\
\hline FN & Clarivate Analytics Web of Science \\
& VR 1.0 \\
PT & J \\
SO & title of the article \\
AU & authors \\
PY & year \\
DE & keywords \\
AB & abstract \\
LA & English \\
SE & Title of edition \\
ER & closing tag \\
\hline
\end{tabular}

Note: at the end of the set, you must insert a tag - EF (closing tag of the list)

Table 1. Results analysis table for Web of Science categories field / Source Titles / Authors (number of articles - $n=$ 181)

\begin{tabular}{|c|c|c|}
\hline $\begin{array}{l}\text { Category, } \\
\text { TOP-10 } \\
\text { items }\end{array}$ & Subject area & Total \\
\hline & Items (n; \%) & $\Sigma$ \\
\hline Subject area & $\begin{array}{l}\text { Sport Sciences (91; } 50.276 \%) ; \text { Hospitality Leisure Sport Tourism (34; } 18.785 \%) ; \\
\text { Psychology Applied (12; } 6.630 \%) ; \text { Orthopedics (9; } 4.972 \%) ; \text { Psychology Multidisciplinary } \\
\text { (9; } 4.972 \%) ; \text { Rehabilitation (7; 3.867 \%); Psychology (5; } 2.762 \%) ; \text { Public Environmental } \\
\text { Occupational Health (5; } 2.762 \%) ; \text { Communication (4; } 2.210 \%) ; \text { Education Educational } \\
\text { Research (4; } 2.210 \%) .\end{array}$ & 55 \\
\hline Source Titles & 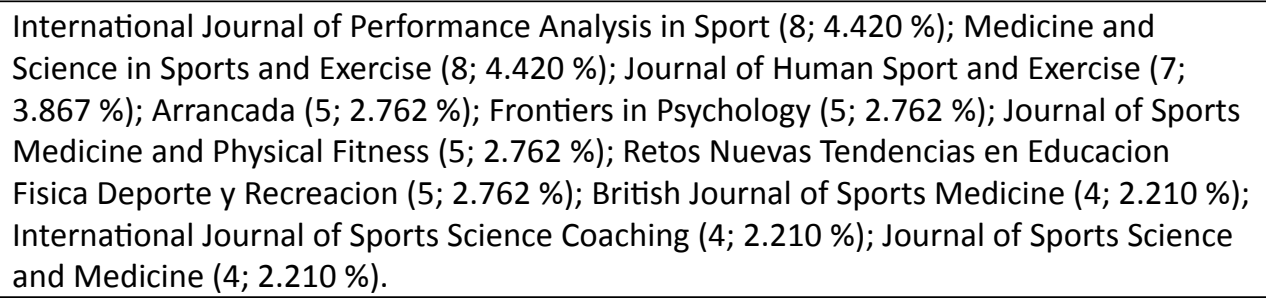 & 119 \\
\hline Authors & $\begin{array}{l}\text { Palao JM (11; } 6.077 \text { \%); Jimenez-Olmedo JM (8; } 4.420 \%) \text {; Penichet-Tomas A (8; } 4.420 \\
\%) ; \text { Perez-Turpin JA (7; } 3.867 \%) ; \text { Medeiros AIA (6; } 3.315 \%) ; \text { Pueo B (6; } 3.315 \%) ; \text { Garcia } \\
\text { GMG (5; } 2.762 \%) \text {; Giatsis G (5; } 2.762 \%) ; \text { Kuijer PPFM (5; 2.762 \%); Link D (5; } 2.762 \%) \text {. }\end{array}$ & 515 \\
\hline
\end{tabular}

Note: $\mathrm{n}$ - number of articles, \% - percentage of the total number of articles); $\Sigma$ - total; source of information - authors' own research (16.06.2021). 
Data analysis.

The purpose of the data analysis is to identify the leading leaders and trends in beach volleyball issues. We used the guidelines for bibliometric analysis [73-75]; bibliometric analysis and systematic review [76, 77].

For this we used the VOSviewer 1.6.17 program [78]. The methodology for calculating the main indicators for analysis and identification of the most significant studies is detailed in the works of van Eck and Waltman [79, 80]. The validity of this approach is confirmed in studies of human physical activity $[81,82]$, the impact of the COVID-19 pandemic on sports [82].

\section{Results}

A search query for the keywords "beach volleyball" in the WoS database forms the section "Analyze Results". From this section, information was extracted that relates to three criteria: Subject area, Source Titles, Authors (Table 1.). The most significant and more popular are the following: subject categories - Sport Sciences (50.276\%), Hospitality Leisure Sport Tourism (18.785\%); Magazines - International Journal of Performance Analysis in Sport (4.420\%); Medicine and Science in Sports and Exercise (4.420\%); Journal of Human Sport and Exercise (3.867\%); Authors - Palao JM (6.077\%); Jimenez-Olmedo JM (4.420\%); Penichet-Tomas A (4.420\%).

Data visualization is shown in Figure 1.

The most significant keywords are presented in a circle. The size of the circle indicates the importance of the keyword: the larger the diameter of the circle, the more significant the keyword is. The relationship of keywords is defined by lines and distance: the greater the distance, the smaller the relationship is. Figure 2 shows the relationship of the keyword "kinematics" with other keywords.

The most cited documents are shown in Figure 3.

Figure 3 shows that the most cited articles are Engebretsen et al. [83-85].

The relationship between documents can be traced in groups of authors (Fig. 4).

The Figure 4 shows that the research topic "The influence of serve characteristics on performance in men's and women's high-standard beach volleyball" covers 10 interrelated documents in the period 2012-2019 (circle designation - busca2012).

For the period 2014-2021 (Fig. 5), there is a relationship between 7 documents, which are concentrated around the research topic "Physical actions and work-rest time in women's beach volleyball" (designation of the circle - palao2015b).

The result of the analysis of documents in the WoS database in the VOSviewer program (Fig. 3) allows to select groups of related documents on various topics. The research topics of the last 5 years are of the greatest interest. This topic is the most popular among researchers. To do this, you need to move the cursor over the topic of interest in the VOSviewer program. The visual result will be represented by the relationship lines between documents.
Analysis of the SEL database (Russia) shows the relationship of publications by keywords (Fig. 6).

The most requested keyword is "training". This word covers 8 interrelated documents (Fig. 7).

Fig. 7 shows that most of the documents are focused on solving the problems of the training process of athletes.

In the VOSviewer program (section "Creating a map based on text data"), a map was created based on the text data of the SEL database. We used the created data set of SEL database (Table 2). The data visualization map shows the number of the most significant keywords and the relationship between them (Fig. 8, 9).

The most commonly used keywords are training, dynamic, analysis, development (Figure 9). The authors "Kostyukov", "Nirka" have the largest number of documents in the database (Table 3). The authors "Kostyukov" and "Nirka" are distinguished by the criterion of "total link strength" (Table 3). The authors "Kostyukov" and "Nirka" once were leaders in the Russian rating of beach volleyball athletes. Kostyukov Deputy Chairman of the Coaching and Methodological Commission of the Volleyball Federation (Russia), head of the scientific group, professor; Nirka - Head coach of the Russian men's national beach volleyball team [86].

Table 3. Authors with the largest number of publications.

\begin{tabular}{llll}
\hline id & Author & documents & $\begin{array}{l}\text { total link } \\
\text { strength }\end{array}$ \\
\hline 15 & Buczynski, AV & 4 & 2 \\
52 & lordanskaya, FA & 3 & 1 \\
71 & Kostyukov, VV & 17 & 18 \\
73 & Kostyukova, ON & 9 & 14 \\
114 & Nirka, VV & 6 & 8 \\
119 & Pavlov, PV & 4 & 2 \\
137 & Rimavi, AiA & 4 & 7 \\
\hline
\end{tabular}

Search queries on the WoS, SEL databases form the data for which the most popular publications were selected by authors, years, subject categories, and journals. Search queries also made it possible to form a data set, which was analyzed in the VOSviewer program. This approach made it possible to observe the relationship between documents, authors, keywords. All this taken together made it possible to identify the most popular and promising areas of research in beach volleyball.

\section{Discussion}

The purpose of this systematic review is to analyze publications on various beach volleyball issues in Russian-language scientific resources. 333 qualitative studies were identified in the WoS, SEL databases. Only two publications of authors from Ukraine and Russia were found in the WoS database. Also, significant differences were revealed in the research topics of the WoS database 


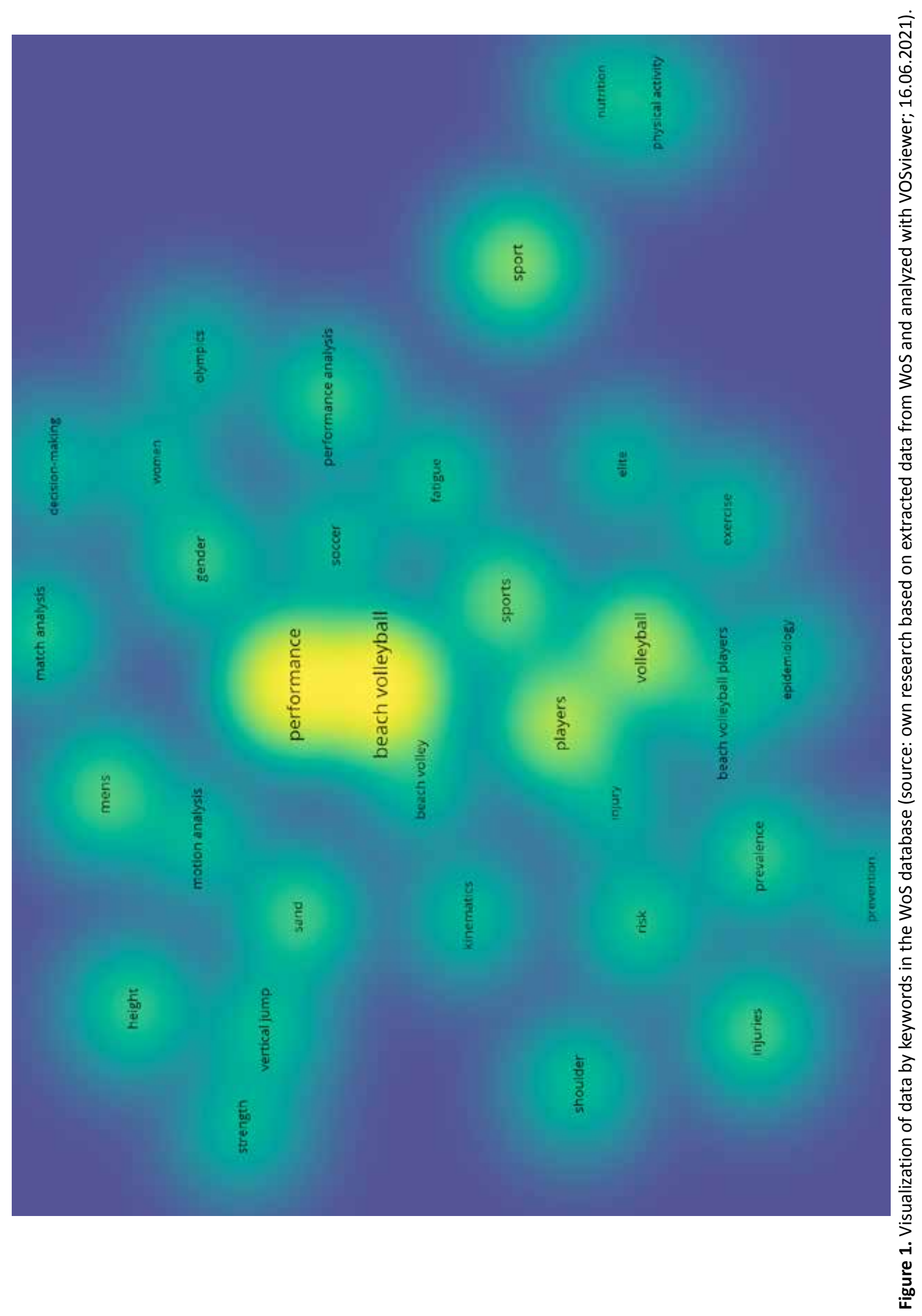




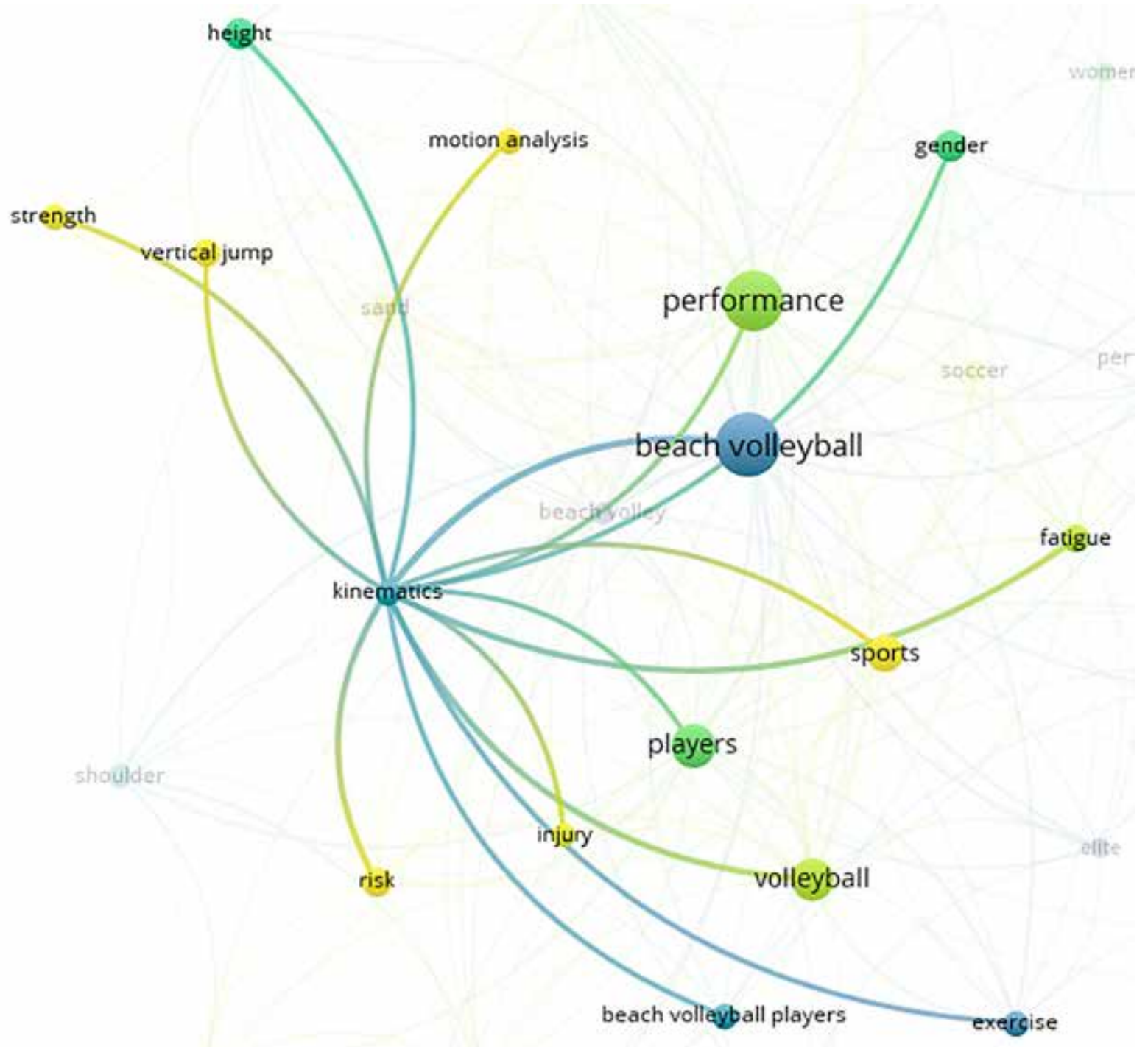

Figure 2. Keyword relationship "kinematics" (source: own research based on extracted data from WoS and analyzed with VOSviewer; 16.06.2021).

and the Russian-language SEL database. The absence of an English-language interface in the SEL database makes it difficult for English-speaking researchers to access publications. This determined the need for the analysis of Russian-language publications on beach volleyball with the subsequent submission of the article to the journal of the WoS database. Complementing this is the fact that SEL's base is located in a country that has been one of the world's leading beach volleyball leaders for many years.

A comparative analysis of the TOP-5 most cited publications shows:

- WoS is represented by the following topics: injuries and diseases of athletes; monitoring of athletes' motor activity; jumping loads.

- SEL is represented by the following topics: beach volleyball in the context of youth health promotion; adaptive responses in athletes; intensification of the training process; psychophysiological features of athletes' competitive potential.

In this context, the most important criterion is the relationship between research groups that are formed around one topic. This relationship can be established by extracting the required data from the WoS / SEL databases with analysis in VOSviewer.

Research topics in the SEL database are presented in several directions. We have identified three of the most important: beach volleyball in the context of recreation and youth health promotion; beach volleyball in the initial stages of training athletes; beach volleyball in the context of elite sports.

Beach volleyball in the context of recreation and health promotion.

Kondrakov et al. [22] developed a functional model of a student's recreational physical culture. The components of the model are the following: motivational and cognitive. The approaches proposed by the authors allow students to achieve the physiologically necessary weekly normal motor load. Similar recommendations for young people and people with disabilities are given by Kryvinia et al. [71]. The authors propose programs for active participation in beach volleyball and seated volleyball competitions as part of the All-Russian Beach Volleyball 


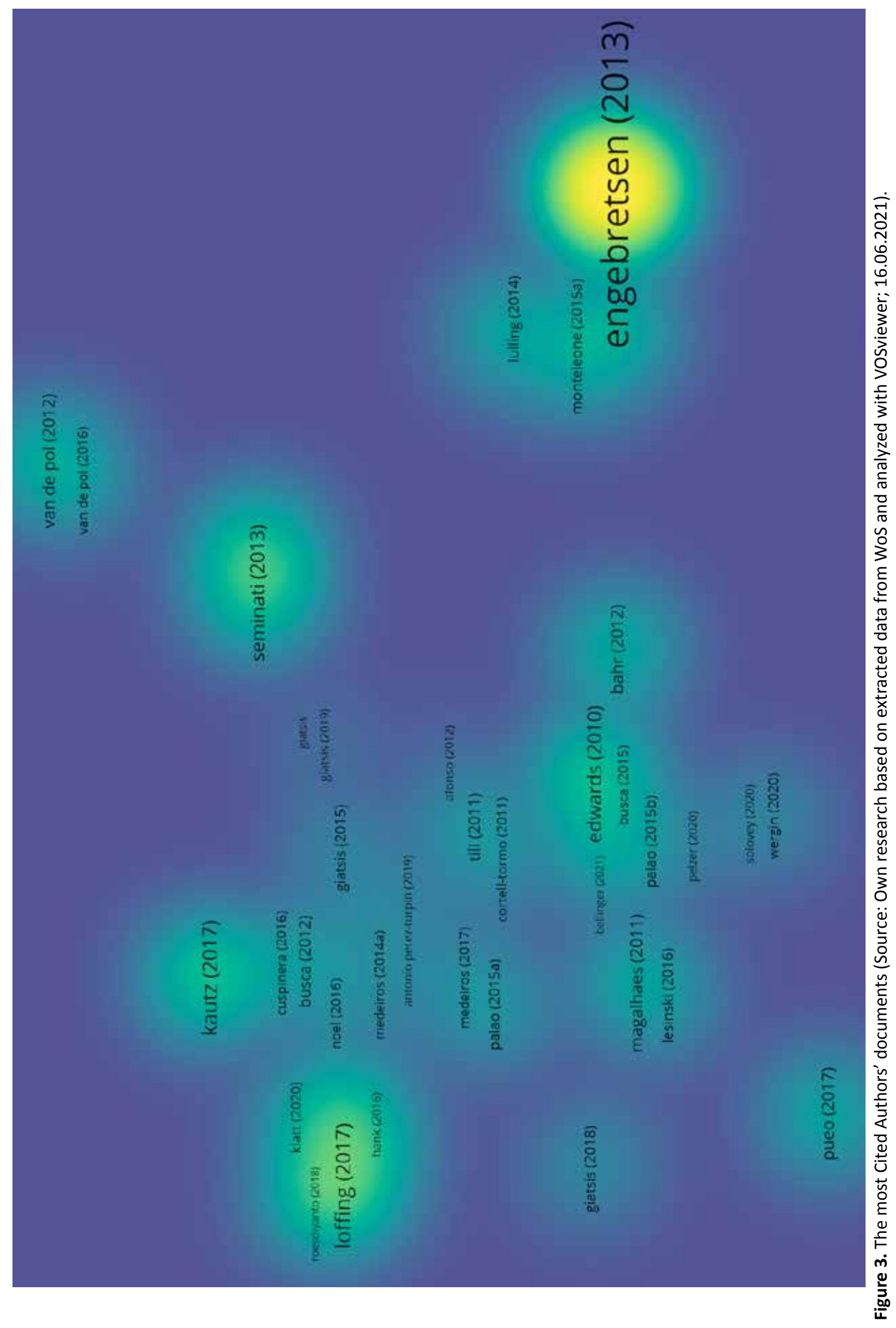




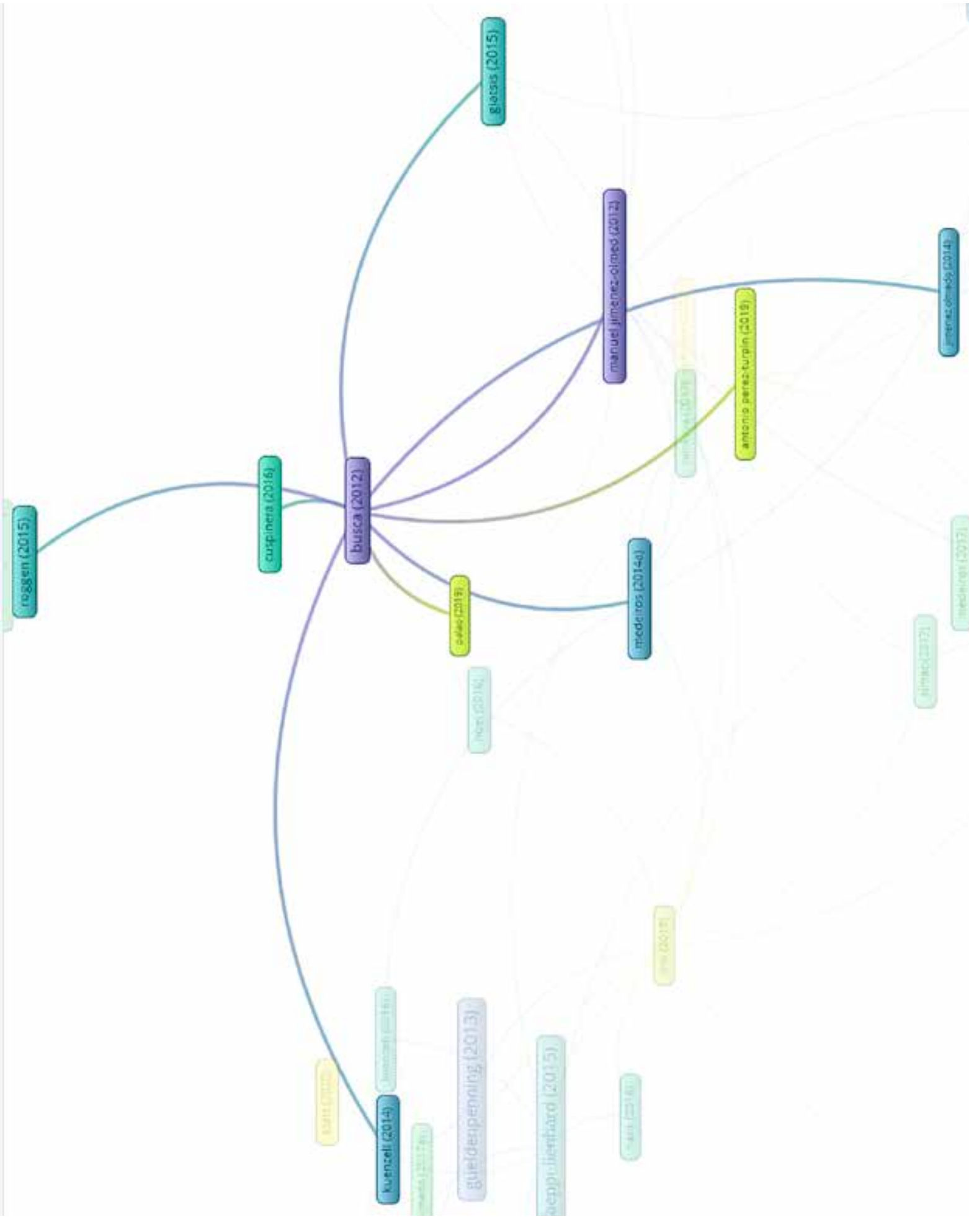

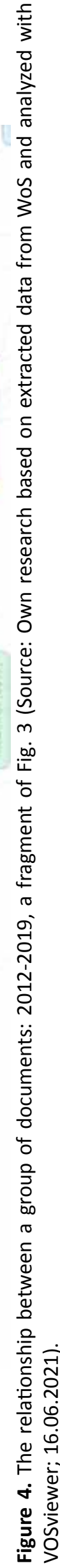




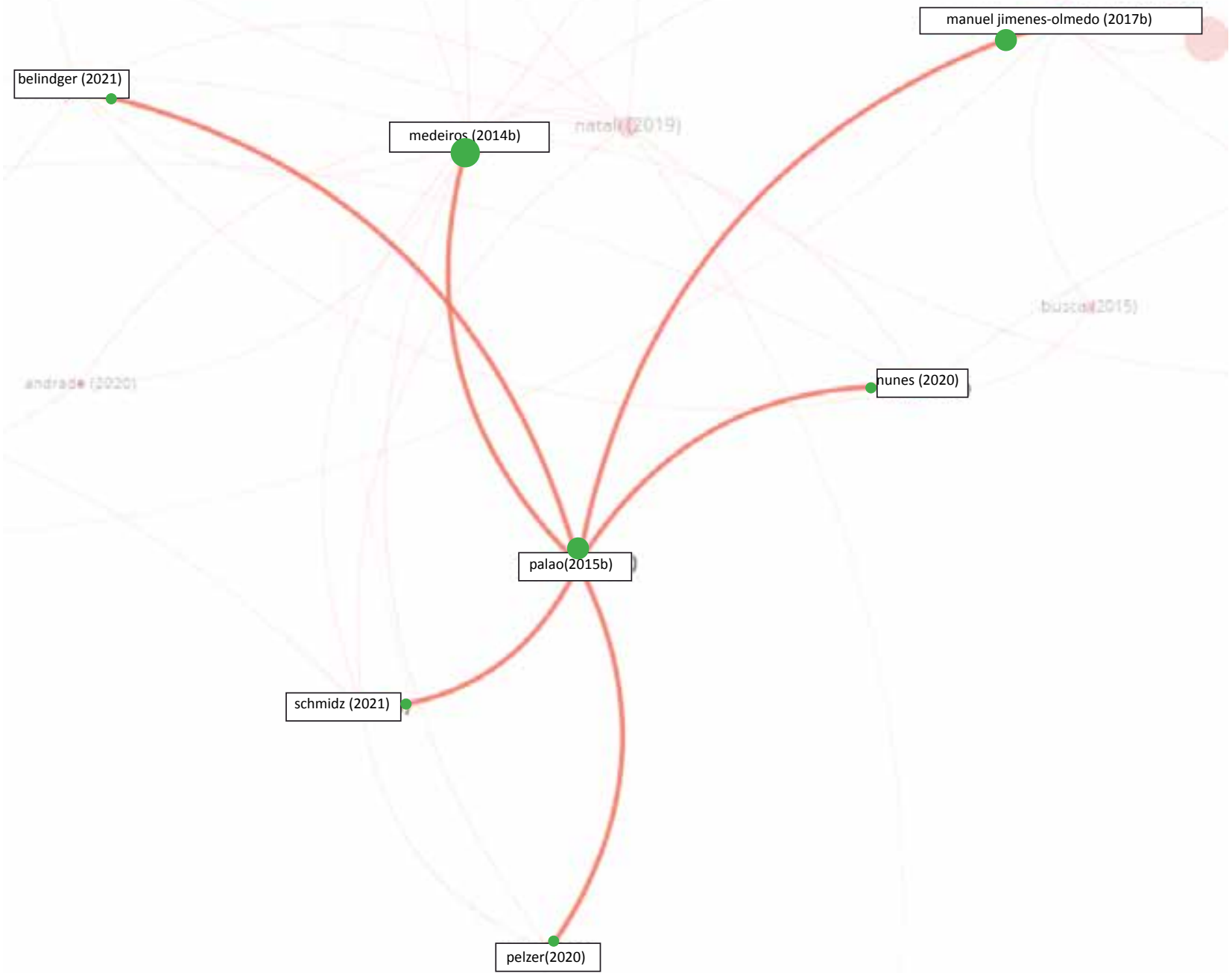

Figure 5. The relationship between a group of documents, 2014-2021, a fragment of Fig. 3 (Source: Own research based on extracted data from WoS and analyzed with VOSviewer; 16.06.2021).

Festival. Bich et al. [70] were developed recommendations for updating the development of a healthy lifestyle for the urban population: revival of industrial gymnastics; active explanatory work of volunteers and lecturers of the Society "Knowledge". This approach is more targeted at the poor.

Rimavi et al. [46] developed a methodology for preparing young men 16-17 years old for passing the control standards of the 5th stage of the All-Russian physical culture and sports complex "Ready for Labor and Defence" (GTO). At the heart of the 48-hour plan (over 8 months) of beach volleyball lessons, there are three types of training (general and special physical, game). This is $2 / 3$ of the total training time. There is an increased number of laureates of the golden sign of the GTO in the group (by 34.1\%). Kortava [64] proposes to actively use beach volleyball in resort areas. The author substantiates the sequence of using the basic means of physical culture: aerobic cyclic exercises, strength exercises for the main muscle groups, beach volleyball. In another similar study, it was shown that it is possible to control the value of the training load during recreational beach volleyball exercises [87].
Kostyukov et al. [88] believe that beach volleyball practice for 16-17 years old boys for two months improves the norms of the 5th stage of the GTO complex. A similar approach was used by Rimavi et al. [46]. The authors present a beach volleyball plan for boys aged 16-17 (48 hours, 8 weeks). The results of 9 tests improved. Three of them are tests from the GTO complex program: $3 \mathrm{~km}$ run (characterizing the development of endurance); long jump and throwing of a sports equipment $700 \mathrm{~g}$ (characterizing speed-power abilities). There is an improvement in test results by $34.1 \%$. Yarysh [89] reports that the health and rehabilitative effects of adult beach volleyball training largely depend on the number of players on the court and the length of the game. By changing these parameters, you can have a different effect on the human body.

We believe that the studies reviewed provide an opportunity to use beach volleyball to prepare the population for national forms of testing. Particular importance should be attached to involving young people in beach volleyball.

Some other studies are presented with short reports on the topic:

- The use of beach volleyball facilities to prepare for 


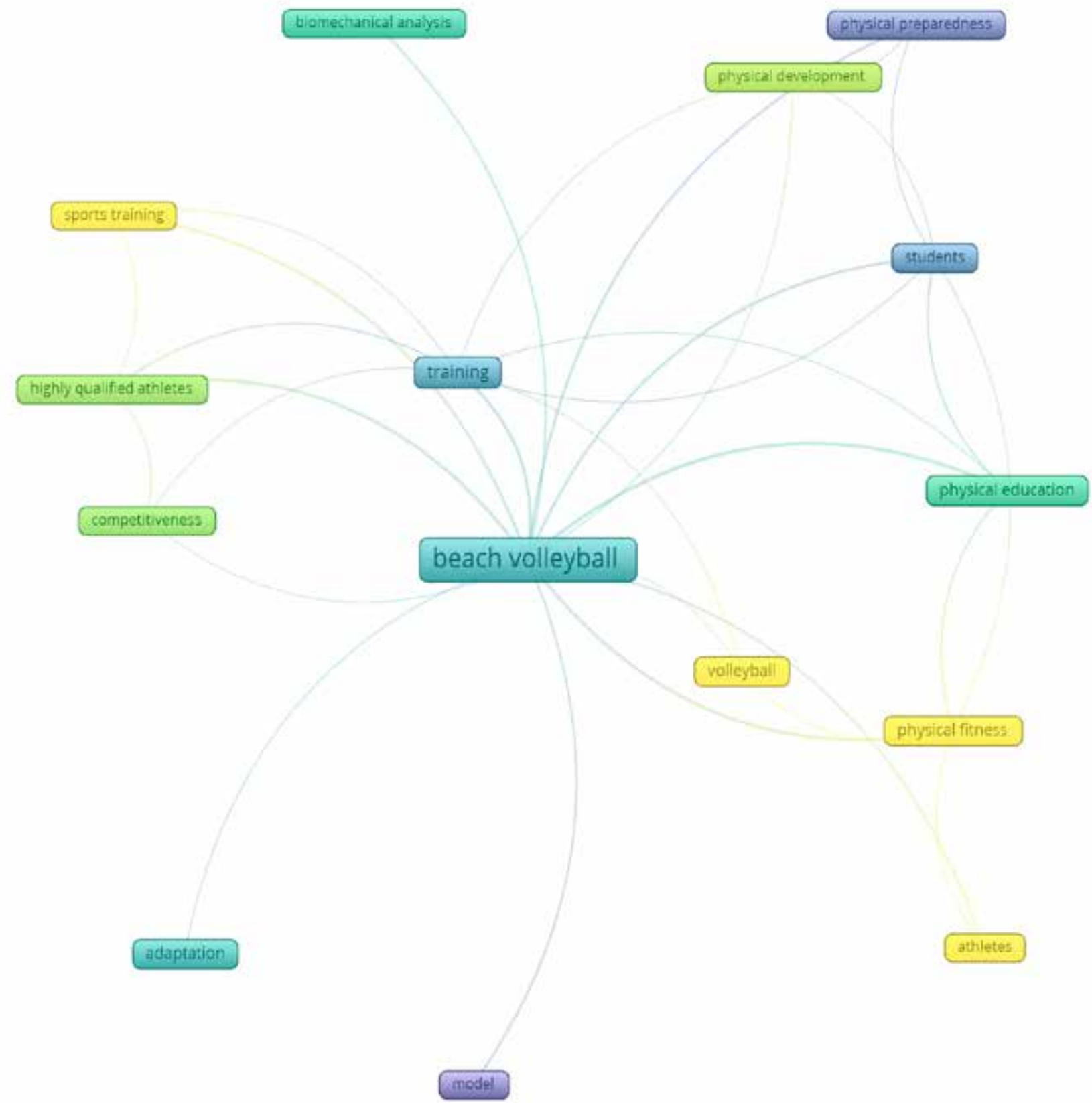

Figure 6. Data visualization by keywords (source: own research based on extracted data from SEL database and analyzed with VOSviewer; 16.06.2021).

the delivery of the standards of the GTO complex [90].

- improving the physical fitness of the younger generation by means of the school sports section in the conditions of a rural school [91].

- recommendations for amateur athletes, which increase efficiency and accelerate the recovery process after exercise [92].

- the content of beach volleyball in the school section and the dynamics of indicators of physical fitness and health of adolescents 14-15 years old [93].

- features of the recreational and health-improving effect of playing beach volleyball on the human body [94].

Unfortunately, short messages do not contain enough information and require additional search and analysis of full texts. However, the existence of such studies indicates a certain interest in the development of topics related to health promotion through beach volleyball.

Beach volleyball in the early stages of training athletes.

The initial stages of training young athletes in beach volleyball have their own distinctive features: selection of young athletes; planning training loads in accordance with the age characteristics of the child's body; motivation to be busy; health promotion and others. Nesterenko et al. [61] consider the training of young female athletes 14-15 years old in the context of two microcycles. The first cycle of a one-year macrocycle: $30-35 \%$ of the total time is allocated for general physical training; the volume of technical training is $35-40 \%$; the volume of tactical, game and special physical training - 25-35\%. The second 


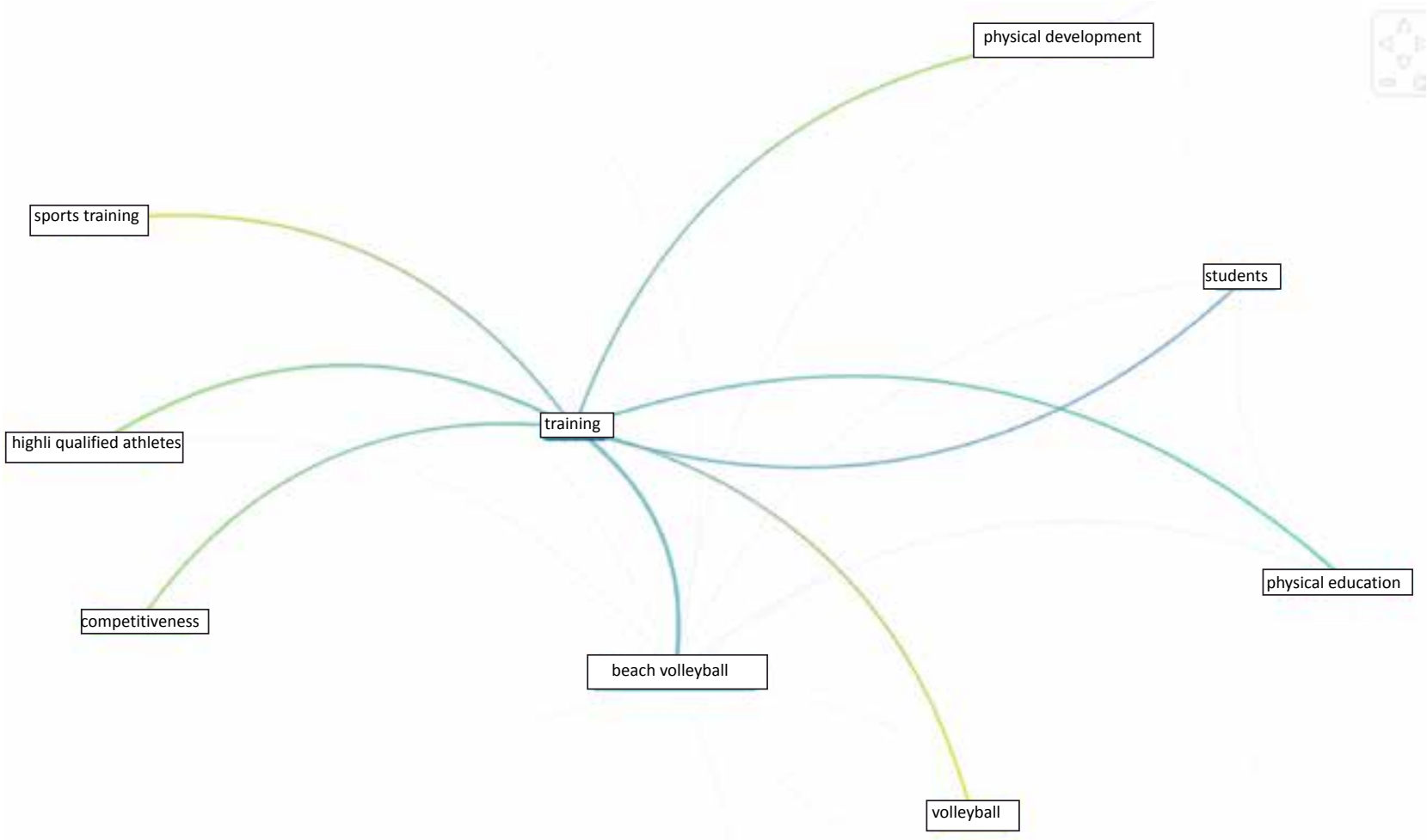

Figure 7. Data visualization by keyword "training" (source: own research based on data extracted from SEL database and analyzed with VOSviewer; 16.06.2021).

cycle of a one-year macrocycle: general physical training is planned in the amount of $20-25 \%$ of the total time; technical - 30-35\%; tactical, game and special physical training - 40-50\%. Koval'chuk et al. [95] established the optimal ratio of the types of the body constitution of young female volleyball players. The authors used data from medical records and subjective assessment of external indicators of physique. Kudashova et al. [96] studied the morphological and functional indicators of girls 9-11 years old who have been playing beach volleyball for 5 months. The authors did not find the effect of training loads on morphological and functional indicators. The relationship between morphofunctional indicators and the level of development of physical qualities and the accuracy of performing technical actions was established. The authors also assessed the peculiarities of adaptation of the organism of volleyball players to physical activity in the preparatory period. Medium and above average relationships were established between functional and technical indicators and low with speed capabilities. Samoday [97] surveyed 25 pupils of primary training groups (age 12 years). The indicators of self-assessment of the mental state of young men were considered. A slightly overestimated assessment of wellbeing, activity and mood was revealed. According to the psychological indicators of concentration, steadfastness and concentration of attention, the average level of their development was established.

In our opinion, the recommendations of the authors fully meet the requirements of the theory and methodology of youth sports. It should be noted that such research is purely pedagogical. We believe that the use of modern instrumental techniques will be a good addition to such studies.

Some other studies are presented with short reports on the topic:

- analysis of body composition components [98].

- gives a brief description of the psychological and structural features that affect the choice of role in volleyball at the initial stage of training [99].

- $\quad$ analysis of the training of the sports reserve in beach volleyball in the Russian Federation [100].

- psychological characteristics of young athletes at the initial stage of sports training [97].

Unfortunately, short messages do not contain enough information and require additional search and analysis of full texts. However, the fact of the existence of such studies indicates a certain interest in the development of topics related to the preparation of a sports reserve in beach volleyball.

Beach volleyball in the context of elite sports

The level of physical activity in elite beach volleyball requires proper pedagogical and medical supervision. These directions are of particular importance for the national teams of the country. From these positions, Iordanskaya et al. [42] consider the diagnosis and assessment of the functional state of athletes in the context of the preparation of Russian national teams. The functional diagnostic testing program has been tested over 8 years of dynamic observations. The criteria for assessing the adaptation of the functions of the cardiovascular and autonomic nervous system, urgent adaptation to physical activity and recovery have been developed. This approach allows to determine the "weak links" of adaptation and 


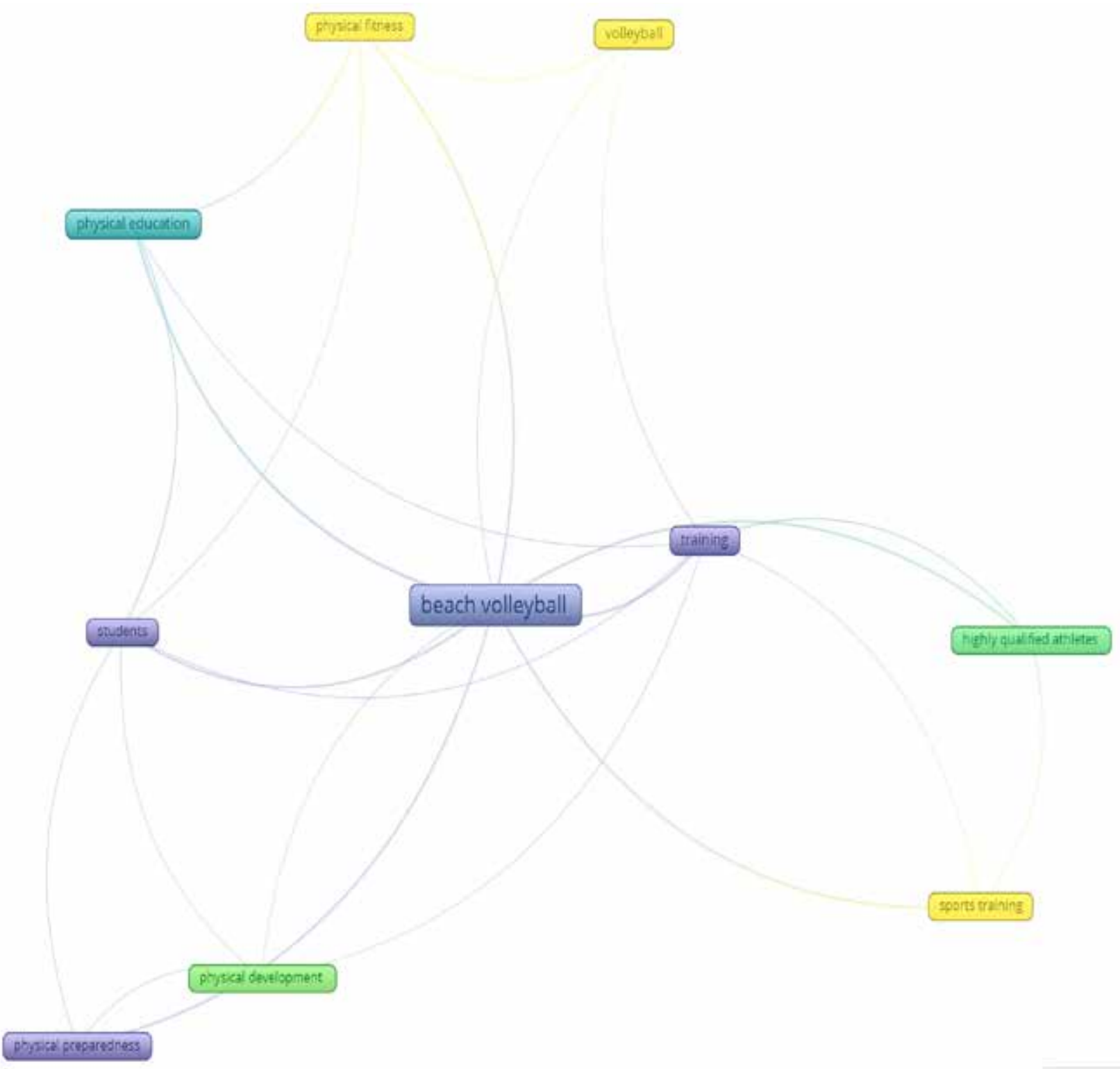

Figure 8. Data visualization of the relationship of 10 keywords (source: own research based on extracted data from the SEL database and analyzed with VOSviewer; 16.06.2021).

factors limiting performance. In another study of athletes of national teams of Russia [56], pre-competition changes in the indicators of the psychological status of athletes were revealed. The authors conclude that the parameters of the psychological status (external and internal motivation for training with statistically significant improvements) of athletes should be used in the process of monitoring the level of their noise immunity and competitiveness at the stages of pre-competitive training.

Pogrebnoy et al. [29] considered the features of technical and tactical training, training process, competitive activity and psychological training of elite athletes. The authors highlighted the biomechanical features of the combined effect of the arm swing on the athlete's peak power output when jumping on a sandy surface. Differences in the physiological reactions of athletes were revealed, taking into account their position on the field. The optimal physiological zones of the intensity of work and recovery of athletes during games have been determined. The authors recommend a psychological technique for increasing the effectiveness of psychomotor control, improving the technique and accuracy of the delivery. The importance of a biomechanically justified technique of pushing an athlete off a sandy surface is shown in the work of Gorchanuk [69]. The author provides a comparative biomechanical analysis of the repulsion technique of athletes from hard and sandy surfaces. Particular attention should be paid to the phase of the last step before pushing off and the position of the feet in contact with the sandy surface. In another similar study [67], the author recommends: when pushing off, it is necessary to maintain the horizontal position of the feet throughout the period of interaction with the support; perform jumping exercises both on dry and slightly wet sand.

It should be noted that the study of biomechanical 


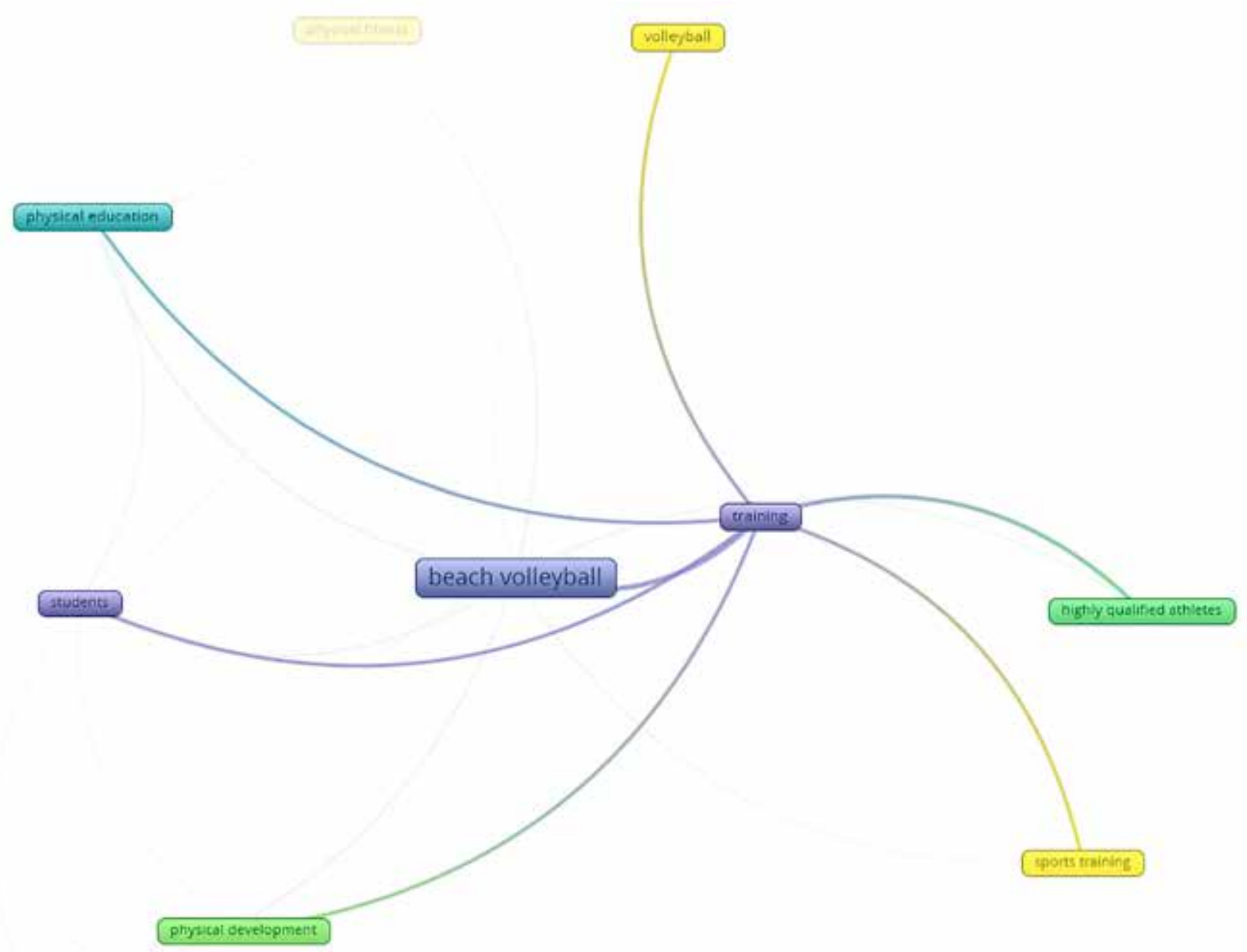

Figure 9. Relationship of the keyword "training" with other words (source: own research based on data extracted from SEL database and analyzed with VOSviewer; 16.06.2021).

parameters of athletes' movement technique is limited by environmental conditions. Large errors in measurements are possible when an athlete moves on a sandy surface. In our opinion, special attention should be paid to the possibility of using measuring equipment on sandy surfaces.

Another study [62] considered the method of early diagnosis of the state of bone metabolism in elite athletes at the stage of pre-competition training. The authors concluded that with prolonged extreme (or forced loads exceeding the limits of physiological tissue resistance), the formation of overvoltage or microtrauma is possible. This leads to disruption of the structure and function of the tissues of the skeletal system. The authors present the main directions of building an injury prevention system: early diagnosis of bone metabolism overload.

Nirka et al. [32] analyzed the three-year dynamics of efficiency and effectiveness indicators of competitive actions of the strongest Russian athletes. There was no significant lag of the Russian athletes from the TOP-5 teams of the world tour in the efficiency and effectiveness of playing elements. The authors presented approaches to the formation of the Olympic time periods of the process of long-term training of athletes of the national team.

In a study with the participation of athletes from national teams of the country [58], a methodology for training athletes is presented, which contains: projective, meaningful, technological and control and accounting modules. The presence of such modules increases the ability to effectively manage the pre-competitive training process. The structure of the stage of direct preparation includes the retractor (12 days), preparatory (15 days) and pre-competition (9 days) mesocycles. The authors revealed statistically significant improvements in $48.5 \%$ of measurements. This is 2.3 times more than with traditional training.

In our opinion, Russian-speaking resources are well represented by studies with the participation of athletes from national teams. The high level of reliability of the results is confirmed by the fact that the research programs have been developed and implemented by an integrated scientific group of Russian national teams. It is also important that these studies had financial state support.

Among the results of other studies, the following can be highlighted:

- The relationship between psychophysiological abilities and sports results has been shown. This made it possible to develop the main directions for improving the process of annual training of athletes [37].

- Identified priority technical elements of the game in defence and special physical qualities that require 
improvement and development [35].

- The psychological status of the athlete has been determined. Indicators of psychomotor skills are presented, which can be used as model characteristics in the selection and diagnosis of players [101].

Some other studies are presented with short reports on the topic:

- The development of psychophysiological indicators and the training program for beach volleyball judges $[102,103]$.

- A program for monitoring the health and functional state of athletes [104].

- The effectiveness of the competitive activity of athletes [105].

- Psychological support for the training of athletes [106].

- Adaptive reactions of the body of athletes to physical activity in mid-altitude conditions [107].

- Adaptation of athletes' sports movements technique [108].

- Computer technologies for biomechanical analysis of attacking blow in beach volleyball [109].

- Features of training elite athletes in the pre-Olympic season [110].

- A program to improve interpersonal compatibility in pairs of athletes [111].

Unfortunately, short messages do not contain enough information and require additional search and analysis of full texts. However, the existence of such studies indicates a certain interest in the development of topics related to the training of elite athletes.

In our opinion, the above studies are more focused on the training of athletes from student teams and amateur athletes. In this context, we have extracted publications from the SEL database on the topic "beach volleyball in the process of physical education of university students".

The need to borrow beach volleyball techniques for the full and comprehensive development of young people is shown in the study by Rozhnov et al. [112]. In another study [22], a functional model of a student's recreational physical culture was developed, which is focused on the formation of students' knowledge of means, methods and organizational forms of independent studies in recreational areas. Smirnov [113] believes that optional beach volleyball classes are a good means of physical self-improvement of students. This is confirmed in other studies [24, 38, 48, 72, 114, 115].

In the context of the studies reviewed, we note that beach volleyball is widely used as a means of promoting the health of student youth. To this can be added the opportunities for youth to participate in beach volleyball competitions. This approach allows us to build a coherent system of training student and children's beach volleyball teams.

Some other studies are presented with short reports on the topic:

- motivation to practice beach volleyball among students [116].

- development of coordination abilities and speed qualities of senior pupils in the process of beach volleyball [117].

- models of development and popularization of volleyball in Kazakhstan [118].

- increasing the motor activity of 16-17 years old boys, based on the use of beach volleyball means [119].

Unfortunately, short messages do not contain enough information and require additional search and analysis of full texts. However, the existence of such studies indicates a certain interest in the development of topics related to the physical education of young people and strengthening their health by means of beach volleyball.

It should be noted that the quality of the short messages does not allow us to draw convincing conclusions on the topics covered in them. This is due to the fact that short reports do not give us the opportunity to reproduce the full cycle of the stated research. Brief communications are evidence of the need for high-quality forward-looking research on the topics stated in them.

In our opinion, the characteristic features of the Russian-language resources of the SEL database are the following:

- research with the participation of athletes from the national teams of the country (with a sufficient level of state financial support) and other elite athletes;

- research focused on improving the health of schoolchildren and university students;

- research with a low level of funding;

- research in the context of the theory of sports and the theory and methodology of physical education of various groups of the population;

- research with sufficiently large opportunities to attract participants - schoolchildren, students, people with disabilities, world-class athletes;

- research carried out in various climatic conditions (coasts - the Baltic Sea, the Caspian Sea, the Black Sea, the South Caucasus coast; sandy areas in recreation areas among a large number of large and small rivers and other bodies of water).

All of these aspects give some advantages in organizing and conducting research on beach volleyball problems in comparison with others (countries whose authors are represented by publications in the WoS database). Ultimately, this affects the quality of the research itself.

\section{Conclusions}

The approaches to extracting data from the SEL database and presenting them in international formats of the WoS database can be used in systematic reviews on other topics. The research results have a good rationale for their use in the training of novice athletes, university students, youth and elite athletes. Differences in the content of research between Russian-language and Englishlanguage resources are a good complement to each other. This fact may contribute to solving the problems of beach volleyball and international cooperation of researchers.

\section{Conflicts of Interest}

The authors declare no conflict of interest. 


\section{References}

1. Dyreson M. The republic of consumption at the Olympic Games: globalization, Americanization, and Californization. Journal of Global History. 2013;8(2):256-278. https://doi.org/10.1017/s1740022813000211

2. Escudero MEQ, Martin AP, Montesdeoca SS, Ruiz DR, Manso JMG. Anthropometric values of spanish beach volleyball players in relation to sports performance level. Revista Brasileira De Medicina Do Esporte. 2020;26(3):206-210. https://doi.org/10.1590/1517-869220202603116858

3. Gea GM, Molina JJ. Analysis of the defense system of the net in women's beach volleyball. Ricyde-Revista Internacional De Ciencias Del Deporte. 2013;9(33):282-297. https://doi.org/10.5232/ricyde2013.03306

4. Zemkova E, Vilman T, Cepkova A, Uvacek M, Olej P, Simonek J.Enhancementofpowerin the concentric phase of the squatand jump: Between-athlete differences and sport-specific patterns. Journal of Human Sport and Exercise. 2017;12(1):29-40. https://doi.org/10.14198/jhse.2017.121.03

5. Knoblochova M, Mudrak J, Slepicka P. Achievement goal orientations, sport motivation and competitive performance in beach volleyball players. Acta Gymnica. 2021;51. https://doi.org/10.5507/ag.2021.016

6. Poczwardowski A, Lamphere B, Allen K, Marican R, Haberl P. The 5C's Model of Successful Partnerships in Elite Beach Volleyball Dyads. Journal of Applied Sport Psychology. 2020;32(5):476-494. https://doi.org/10.1080/10413200.2019.1573205

7. Lau ES, Chung HJ, Hwa MCY. Voices of Singapore national beach volleyball female athletes: What is an ideal coach? International Journal of Sports Science \& Coaching. 2020;15(5-6):642-652. https://doi.org/10.1177/1747954120941304

8. Giatsis G, Schrapf N, Koraimann T, Tilp M. Analysis of the arm swing technique during the spike attack in elite beach volleyball. International Journal of Performance Analysis in Sport. 2019;19(3):370-380. https://doi.org/10.1080/24748668.2019.1611291

9. Medeiros AIA, Mesquita IM, Marcelino RO, Palao JM. Effects of technique, age and player's role on serve and attack efficacy in high level beach volleyball players. International Journal of Performance Analysis in Sport. 2014;14(3):680-691. https://doi.org/10.1080/24748668.2014.11868751

10.Ramon-Llin J, Sanchez-Alcaraz BJ, Sanchez-Pay A, Guzman JF, Vuckovic G, Martínez-Gallego R. Exploring offensive players' collective movements and positioning dynamics in high-performance padel matches using tracking technology. International Journal of Performance Analysis in Sport, 2021:1-12. https://doi.org/10.1080/24748668.2021.1969508

11.Kunzell S, Schweikart F, Kohn D, Schlappi-Lienhard O. Effectiveness of the Call in Beach Volleyball Attacking Play. Journal of Human Kinetics. 2014;44(1):183-191. https://doi.org/10.2478/hukin-2014-0124

12.Link D, Wenninger S. Performance Streaks in Elite Beach Volleyball - Does Failure in One Sideout Affect Attacking in the Next? Frontiers in Psychology. 2019;10. https://doi.org/10.3389/fpsyg.2019.00919

13.Knoblochova M, Mudrak J, Slepicka P. Achievement goal orientations, sport motivation and competitive performance in beach volleyball players. Acta Gymnica. 2021;51. https://doi.org/10.5507/ag.2021.016

14. Solovey O, Hunchenko V, Solovey D, Wnorowski $\mathrm{K}$. Influence of static balances level on competitive performance indicators of athletes 17-21 years old in beach volleyball. Phys Educ Stud. 2020;24(6):332-339. https://doi.org/10.15561/20755279.2020.0605

15.Jimenez-Olmedo JM, Penichet-Tomas A. Injuries and pathologies in beach volleyball players: A systematic review. Journal of Human Sport and Exercise. 2015;10(4):936-948. https://doi.org/10.14198/jhse.2015.104.09

16.Monteleone G, Gismant M, Stevanato G, Tiloca A. Silent deltoid atrophy in beach volleyball players: a report of two cases and literature review. International Journal of Sports Physical Therapy. 2015;10(3):347-353.

17.Cheron C, Le Scanff C, Leboeuf-Yde C. Association between sports type and overuse injuries of extremities in adults: a systematicreview. Chiropractic\& Manual Therapies. 2017;25. https://doi.org/10.1186/s12998-017-0135-1

18.Ahmad Z, Murakami AM, Engebretsen L, Jarraya M, Roemer FW, Guermazi A, et al. Knee cartilage damage and concomitant internal derangement on MRI in athletes competing at the Rio de Janeiro 2016 Summer Olympics. Eur J Radiol Open. 2020;7:7. https://doi.org/10.1016/j.ejro.2020.100258

19.Closs B, Burkett C, Trojan JD, Brown SM, Mulcahey MK. Recovery after volleyball: a narrative review. Physician and Sportsmedicine. 2020;48(1):8-16. https://doi.org/10.1080/00913847.2019.1632156

20.Doyscher R, Kraus K, Finke B, Scheibel M. Acute and overuse injuries of the shoulder in sports. Orthopade. 2014;43(3):202-210. https://doi.org/10.1007/s00132-013-2141-x

21.Marques NK. Effect of the floor in the lower limbs of the volleyball player: a review about the jump. Revista Inclusiones. 2017;4:144-159.

22.Kondrakov GB, Andryushchenko LB, Yablochkina IV, Podoruev YV. Recreational physical culture formation concept for university of economics. Theory and Practice of Physical Culture, 2016;9(6):22-24.

23.Smirnov VN. Open Classroom in Beach Volleyball as a Method of Physical Self-Perfection of First-Year Students. Teoriya i pracktika fizicheskoy kultury. 2014(2):31-31.

24.Smirnov VN, Likhachev OE. Beach Volleyball Competitions in Physical Education of Students (Case Study of Agrarian University). Teoriya $i$ pracktika fizicheskoy kultury. 2013(4):60-60.

25.Parkhomenko NN. Preparation of Russian Athletes forthe XXIX Olympics-2008 in Beijing (China). Teoriya i pracktika fizicheskoy kultury. 2008(3):40-42.

26.Smirnov VV, Kolyago PV, Kostukov VV. Dynamics of Model Characteristics of Leading Athletes of National Beach Volleyball Teams. Teoriya i pracktika fizicheskoy kultury. 2008(7):60-60.

27.Scientific Electronic Library eLIBRARY.RU. [Internet]. 2021 [updated 2021 Aug 20; cited 2021 Sep 02]. Available from: https://elibrary.ru/defaultx.asp

28.Repositary of Academic Texts (Ukraina). [Internet]. 2021 [updated 2021 Aug 20; cited 2021 Sep 02]. Available from: https://nrat.ukrintei.ua/en/searchdb/

29.Pogrebnoy AI, Komlev IO, Litvishko EY. Modern world trends of sports training in beach volleyball (review of foreign literature). Fizicheskaya Kultura, Sport - Nauka i Praktika, 2020:83-9. https://doi.org/10.53742/1999-6799_2020_03 83

30. Mishchuk DN. Modern trends of development of volleyball in the World and Ukraine. Aktual'nye nauchnye issledovaniia $v$ sovremennom mire, 2020;2-4(58):108-111.

31.Nirka VV, Kostyukov VV, Kolesnikova EA, Kostyukova ON. Long-term dynamics of efficiency and effectiveness of 
competitive actions high-skilled players in beach volleyball. Kul 'tura fizicheskaia i zdorov'e, 2017;2(62):39-42.

32.Nirka V, Kostyukov V. Changes of effectiveness of competitive activity of beach volleyball athletes in the olympic training cycle. Fizicheskaia kul tura, sport - nauka $i$ praktika, 2016;3:14-17.

33.Buczynski AV. Options to perfect spike techniques in beach volleyball. Fizicheskaia kul'tura. Sport. Turizm. Dvigatel'naia rekreaciia, 2018;3:19-24.

34.Buczynski AV, Pavlov PV. Assessment of the informativeness of the objective parameters of the attacking blow in beach and classic volleyball. Uchenye zapiski. Elektronnyj nauchnyj zhurnal Kurskogo gosudarstvennogo universiteta, 2017;3(43):219-222.

35.Gunchenko VV. Quality of receiving a serve as factor influence on the level of setting and the results of competitive activity in the beach volleyball. Aktual'nye nauchnye issledovaniia $v$ sovremennom mire, 2019;5-3(49):16-25.

36.Rodin AV, Pustoshilo PV. The pedagogical program for the assessment of individual technical and tactical actions of athletes in student's classical and beach volleyball. Izvestiia Smolenskogo gosudarstvennogo universiteta, 2016;1(33):298-304.

37.Dashaev KA. Psychophysiological aspects of training of athletes in beach volleyball taking into account stress factor analysis. Izvestiia Chechenskogo gosudarstvennogo universiteta, 2021:115-23. https://doi.org/10.36684/12-2021-22-2-115-123

38.Kostyukov V, Dashaev D, Maaev H. Dynamics of game, technical and tactical training of schoolchildren and students in the process of beach volleyball training. Fizicheskaia kul tura, sport - nauka i praktika, 2014;2:19-23.

39.Dorontsev AV, Ermolina NV, Mayorova EB, Lyamina YA. The effectiveness study of park volleyball use during extracurricular activity of senior pupils. Pedagogikopsikhologicheskie $i$ mediko-biologicheskie problemy fizicheskoj kul'tury $i$ sporta, 2020;15(1): 115-119. https://doi.org/10.14526/2070-4798-2020-15-1-115-119

40.Mazurina AV, Bobkova EN, Luganskaia MV, Ignatenko TS. Analysis of the level of physical preparedness of student teams in the training macrocycle on the beach volleyball. Vestnik sportivnoj nauki, 2019;1:21-24.

41.Solyukov AA, Egorova AM, Bekmukhambetova LS.The characteristic of physical fitness of school students of 13-15 years playing volleyball. Vestnik KGPI, 2017;3:72-78.

42.Iordanskaya FA, Buchina EV, Kochetkova NI, Nirka VV. Functional and diagnostic testing of athletes in beach volleyball at stages of preparation for principal competitions. Vestnik sportivnoj nauki, 2017;1:37-45.

43. Rozhnov AA, Dobejko NI, Fedorov VA. Creation of process of physical education of the first-year female students on the basis of the sports-oriented technology. Vestnik Adygejskogo gosudarstvennogo universiteta. Seriia 3: Pedagogika $i$ psikhologiia, 2017;4(208):176-183.

44.Mishchuk DM. Integrated control in volleyball at the initial stages of long- term preparation. Aktual'nye nauchnye issledovaniia $v$ sovremennom mire, 2020;5-6(61):65-69.

45.Koval'chuk DR, Povietkina AA, Kuzniecov VA. Evaluation of physical development indicators of young athletes specializing in volleyball taking into account their somatotype. Aktual'nye nauchnye issledovaniia $v$ sovremennom mire, 2020;6-5(62):82-86.

46.Rimavi AIA, Reshetniak MV, Kostyukov VV, Kostyukova ON. Preparation methodology of senior high school students for passing the standards of the «ready for the labour and defence» complex using the means of beach volleyball. Fizicheskaia kul'tura, sport - nauka i praktika, 2018;3:9-15.

47.Kostyukov VV, Barzylovich KI, Zevriev EE, Kharlamov NN. Intensification of trainings in classic and beach volleyball as a factor in increasing the competitiveness of people going in for different sexes and the level of fitness. Resursy konkurentosposobnosti sportsmenov: teoriia $i$ praktika realizacii, 2018;1:122-123.

48.Maksimova EN, Smirnov VN, Lihachev OE. Specific features of use of beach volleyball in physical training of students of higher schools. Uchenye zapiski universiteta im. P.F. Lesgafta, 2013;3(97):125-129.

49.Kolyago P. Dynamics of the level of physical preparedness in a year athletes training in beach volleyball. Fizicheskaia kul tura, sport - nauka i praktika, 2009;4:14-17.

50.Povareshchenkova YuA, Kozlov AA. Evaluating of cardiovascular adaptation system in a beach volleyball player. Aktual'nye problemy zdorov'ia i fizicheskoj kul'tury, 2014;1:51-54.

51.Povarioshchenkova JA, Kozlov AA, Osetrov IA. Control of the functional state of beach volleyball players in the precompetition period. Iaroslavskij pedagogicheskij vestnik, 2013;3(3):131-135.

52.Kozlov AA, Povareshchenkova YUA. Investigation of cardiac rhythm regulation in evaluation of adaptive reactions of cardiovascular system in beach volleyball players. Lechebnaia fizkultura $i$ sportivnaia medicina, 2013;6(114):22-25.

53.Portnih JI, Shanskov MA, Fetisova SL, Shiryaev AM. Particular the psycho-physiological potential player $я$ in classic and beach volleyball. Uchenye zapiski universiteta im. P.F. Lesgafta, 2008;11(45):70-74.

54.Smirnov V. Structure and content of a year training cycle for athletes specializing in beach volleyball. Fizicheskaia kul'tura, sport - nauka i praktika, 2009;4:18-22.

55.Rudkovskaia EV. Dynamics of loads in the macrocycle of training young athletes specializing in beach volleyball. Vestnik sportivnoj nauki, 2007;3:62-64.

56.Kostyukov V, Dementieva I, Kostyukova O, Malygin G. Changes in the psychological status of highly qualified athletes in the process of pre-competitive training in beach volleyball. Fizicheskaya Kul'tura, Sport - Nauka i Praktika, 2021:14-8. https://doi.org/10.53742/1999-6799_2021_02_14

57.Abramov SA. Structure and content of training of student volleyball teams. Aktual'nye nauchnye issledovaniia $v$ sovremennom mire, 2021;2-4(70): 127-130.

58.Kostyukov VV, Nirka VV, Glazin AM, Kostyukova ON. Direct preparation of highly qualified athletes for main competitions of the season in beach volleyball. Fizicheskaia kul'tura, sport - nauka i praktika, 2019;4:58-64.

59.Povareshchenkova JA, Kozlov AA. Dynamic researches of the heart rate variability among the beach volleyball players while preparing for responsible competition. Uchenye zapiski universiteta im. P.F. Lesgafta, 2013;11(105):128-133.

60.Kostyukov V, Kolyago P, Smirnov V, Kondratenko M, Baskakov A, Nikolenko R. Modernization of training athletes in beach volleyball in a year period. Fizicheskaia kul'tura, sport - nauka i praktika, 2009;3:18-23.

61.Nesterenko N, Kriukovs'ka O. Analysis of the system of training process of beach volleyball athletes in the annual macrocycle at the stage of specialized basic training. Newsletter of Precarpathian University. Physical culture, 2021:46-53. https://doi.org/10.15330/fcult.36.46-53

62.Iordanskaya FA, Tsepkova NK. Bone metabolism in elite athletes at the precompetitive stage of preparation. Vestnik 
sportivnoj nauki, 2016;6:35-40.

63.Kudashova LR, Kefer NE, Shankulov ET, Samalikova B, Myrzabekova SP. Dynamics of morphofunctional indicators of volleyball players 9-11 years in the preparatory period. Teoriia i metodika fizicheskoj kul 'tury, 2016;2(45):18-23.

64.Kortava ZG. Development of health-improving and recreative technology forphysical training activities at the resort. Uchenye zapiski universiteta im. P.F. Lesgafta, 2015;2(120):72-76. https://doi.org/10.5930/issn.1994-4683.2015.02.120.p72-76

65.Kortava ZhG. The technology of complex application of physical culture means of different orientation in the process of health-improving classes at the resort. Izvestiia Sochinskogo gosudarstvennogo universiteta, 2013;3(26):145-148.

66. Sukhanov AV, Bulykina LV, Guba VP. Impact of trainings on special performance on performance of the game in one-year period in beach volleyball. Izvestiia Tul'skogo gosudarstvennogo universiteta. Fizicheskaia kul'tura. Sport, 2020;7:117-122. https://doi.org/10.24411/2305-8404-2020-10716

67. Goncharuk IaA. Features of the technical training of athletes in beach volleyball. Globus, 2019;12(45):53-55.

68. Buczynski AV, Pavlov PV. On the application of the technology of video capture movements in determination model characteristics attacking blow beach volleyball. Zdorov'e dlia vsekh, 2015;2:30-33.

69.Gorchanuk U. The idealized substantiation and check of efficiency of models of movings and jumps of the sportsmen in beach volleyball. Fizicheskoe vospitanie studentov tvorcheskikh special'nostej, 2003;6:72-87.

70.Bich IuG, Samsonenko TA, Mikhajlova TA. Some aspects of historical and modern experience of implementation of physical and health practices through the example of the «Ready for labour and defence» complex. Fizicheskaia kul'tura, sport - nauka i praktika. 2018;3:62-67.

71.Kryvinia EN, Gutnikov SV, Erokhina MS, Plotnikova SS. The adaptive recreation by means of beach volleyball and sitting volleyball. Adaptivnaia fizicheskaia kul'tura, 2015;3(63):45-46.

72.Ponomarev VV, Limarenko OV, Groshev VA. Organizationally-methodical provision of training curling university students. Zdorov'e dlia vsekh, 2013;2::17-20.

73.López-Carril S, Escamilla-Fajardo P, GonzálezSerrano MH, Ratten V, González-García RJ. The Rise of Social Media in Sport: A Bibliometric Analysis. Int $J$ Innovation Technol Management, 2020;17:2050041. https://doi.org/10.1142/S0219877020500418

74.Donthu N, Kumar S, Mukherjee D, Pandey N, Lim WM. How to conduct a bibliometric analysis: An overview and guidelines. Journal of Business Research, 2021;133:285-96. https://doi.org/10.1016/j.jbusres.2021.04.070

75.AhmadSN, Mas'odA, SulaimanZ,HasbullahNN.Bibliometric Analysis on Motivation of Sport Event Volunteer using the Scopus Database. IJARBSS, 2021;11:Pages 1200-1227. https://doi.org/10.6007/IJARBSS/v11-i3/8832

76.Rialti R, Marzi G, Ciappei C, Busso D. Big data and dynamic capabilities: a bibliometric analysis and systematic literature review.PublishedinManagementDecision,2019;57:2052-68. https://doi.org/10.1108/MD-07-2018-0821

77.Linnenluecke MK, Marrone M, Singh AK. Conducting systematic literature reviews and bibliometric analyses. Australian Journal of Management, 2020;45:175-94. https://doi.org/10.1177/0312896219877678

78.VOSviewer version 1.6.17. [Internet]. VOSviewer, 2021. [updated 2021 July 22; cited 2021 Sep 11]. Available from: https://www.vosviewer.com/ 79.van Eck NJ, Waltman L. Software survey: VOSviewer, a computer program for bibliometric mapping. Scientometrics, 2010;84:523-38. https://doi.org/10.1007/s11192-009-0146-3

80.van Eck NJ, Waltman L. VOSviewer Manual [Internet]. 2018 [updated 2018 Aug 29; cited 2021 Sep 11]. Available from: https://www.vosviewer.com/documentation/Manual VOSviewer_1.6.9.pdf

81.Müller AM, Ansari P, Ebrahim NA, Khoo S. Physical Activity and Aging Research: A Bibliometric Analysis. Journal of Aging and Physical Activity, 2016;24:476-83. https://doi.org/10.1123/japa.2015-0188

82.Fang H, Jing Y, Chen J, WuY, Wan Y.Recent Trends in Sedentary Time:ASystematicLiterature Review.Healthcare, 2021;9:969. https://doi.org/10.3390/healthcare9080969

83.Engebretsen L, Soligard T, Steffen K, Alonso JM, Aubry $\mathrm{M}$, Budgett $\mathrm{R}$, et al. Sports injuries and illnesses during the London Summer Olympic Games 2012. British Journal of Sports Medicine. 2013;47(7):407-414. https://doi.org/10.1136/bjsports-2013-092380

84.Doyscher R, Kraus K, Finke B, Scheibel M. Acute and overuse injuries of the shoulder in sports. Orthopade. 2014;43(3):202-210. https://doi.org/10.1007/s00132-013-2141-x

85.Eerkes K. Volleyball Injuries. Current Sports Medicine Reports. 2012;11(5):251-256. https://doi.org/10.1249/JSR.0b013e3182699037

86.Seminar for Beach Volleyball Coaches. Application vol.1, 12-14 November 2021. [Internet] 2021. [updated 2021 July 22; cited $2021 \mathrm{Sep} \mathrm{11].} \mathrm{Available} \mathrm{from:} \mathrm{https://www.volley.}$ ru/globals/documents/download.php?id=3916

87.Kortava ZhG, Iarysh IN, Fediakina LK. The health benefits of beach volleyball. Sochi Journal of Economy, 2015;1(34):291-293

88.Kostyukov VV, Dacenko SS, Kostyukova ON. Modeling of the 16-17 year-old -young men's preparation to the implementation of the tasks of the V-th stage of the gto complex at the classes of beach volleyball. Kul'tura fizicheskaia i zdorov'e, 2018;4(68):44-47.

89. Yarysh IN. The influence of the recreative beach volleyball training on mature aged men organism in sanatorium conditions. Uchenye zapiski universiteta im. P.F. Lesgafta, 2008;10(44):111-114.

90.Rimavi A, Kostyukov VV. The use of beach volleyball means to prepare for the delivery of the norms of the GTO complex. Integrirovannye kommunikacii v sporte i turizme: obrazovanie, tendencii, mezhdunarodnyj opyt, 2016;1:40-42.

91.Kurilova VI, Schastlivyj SN, Baranov AN. The role of the physical culture teacher in improving the physical preparation of the adventured generation by the means of the sport section of volleyball. Aktual'nye nauchnye issledovaniia $v$ sovremennom mire, 2019;10-6(54):65-69.

92.Novozhilova SV, Mitrofanova GN, Ignatova EV. Optimization of working capacity of amateur beach volleyball players. Fizicheskaia kul'tura: vospitanie, obrazovanie, trenirovka, 2018;1:56-60.

93.Dashaev K. Dynamics of teenagers' physical preparedness and health in the process of beach volleyball studies. Kul'tura fizicheskaia i zdorov'e, 2014;3(50):19-22.

94.Kortava ZhG, Iarysh IN. The influence of recreational and recreational beach volleyball on the body of an adult. Izvestiia Sochinskogo gosudarstvennogo universiteta, 2013;3(26):149-153.

95.Koval'chuk DR, Povietkina AA, Kuzniecov VA. Somatotypes determination for young athletes who 
specializing in volleyball. Aktual'nye nauchnye issledovaniia $v$ sovremennom mire, 2020;5-6(61):37-39.

96.Kudashova LR, Kefer NE, Shankulov ET, Samalikova B. Assessment of physical and functional indicators of young female volleyball players 9-11 years old in the preparatory period. Teoriia i metodika fizicheskoj kul 'tury, 2016;1(44):4046.

97.Samoday V.Psychological features of youths at a selection to beach volleyball. Pedagogics, Psychology, MedicalBiological Problems of Physical Training and Sports, 2010;4:122-124.

98.Golovin IG, Guba VP. Bioimpedance analysis of body composition in women's beach volleyball. Fizicheskaia kul tura: vospitanie, obrazovanie, trenirovka, 2021;2:28.

99.Abramov SA. Creating a model for selecting a game template at the initial stage of volleyball training. Aktual'nye nauchnye issledovaniia $v$ sovremennom mire, 2019;12-5(56):13-17.

100. Enchenko IV, Zajchikova KN. Analysis of beach volleyball sport reserves preparation in the russian federation. Fizicheskaia kul'tura. Sport. Turizm. Dvigatel'naia rekreaciia, 2019;4(2):34-42.

101. Fetisova SL, Fokin AM, Mel'nikova TI. Features of the psychophysiological potential of beach volleyball players depending on their sports qualifications. Vestnik Baltijskogo federal'nogo universiteta im. I. Kanta, 2014;11:138-146.

102. Zhigunova NV, Kostyukov VV, Kostyukova ON. Qualification changes of beach volleyball referees' psychophysiological indicators. Materialy ezhegodnoj otchetnoj nauchnoj konferencii aspirantov $i$ soiskatelej Kubanskogo gosudarstvennogo universiteta fizicheskoj kul'tury, sporta i turizma, 2019;1:25-28.

103. Zhigunova NV, Kostyukov VV, Kostyukova ON, Nenov GO. The current state of the training of sports judges in beach volleyball. Resursy konkurentosposobnosti sportsmenov: teoriia i praktika realizacii. 2018;1:90-91.

104. Iordanskaya FA, Abramova TF, Cepkova NK. Monitoring of functional fitness of elite athletes and improvement of the programs in the process of training activity. Vestnik sportivnoj nauki. 2018;5:37-44.

105. Nirka VV, Kostyukov VV, Kolesnikova EA. The effectiveness of the competitive activity of athletes specializing in beach volleyball. Fizicheskaia kul tura, sport - nauka i praktika, 2017;4:36-40.

106. Dement'eva IM, Kostyukov VV, Kostyukova ON, Vasil'ev AA. Psychological support of training as a resource for the competitiveness of athletes in beach volleyball. Resursy konkurentosposobnosti sportsmenov: teoriia $i$ praktika realizacii, 2017;7:75-77.

107. Lozbina AV, Rakhimov AA. Influence of trainings in the conditions of middle mountains on biological opportunities of athletes. Vestnik fizicheskoj kul tury i sporta,
2017;2(17):154-160.

108. Buczynski AV, Pavlov PV. To the question of the adaptation of the technique of sports movements by the example of changes in the biomechanical parameters of an attacking blow during the transition from classic to beach volleyball. Aktual'nye problemy razvitiia fizicheskoj kul'tury $i$ sporta $v$ sovremennykh usloviiakh. 2016;1:91-98.

109. Buczynski AV, Pavlov PV. Using video capture for biomechanical analysis of an attack hit in beach volleyball. Uchenye zapiski. Elektronnyj nauchnyj zhurnal Kurskogo gosudarstvennogo universiteta, 2015;2(34):126-130.

110. Rodionov VI, Rebrov SV, Zlishcheva TA, Nikolenko RN, Kostyukov VV. Beach volleyball: features of training highly qualified athletes in the pre-Olympic season. Aktual'nye voprosy fizicheskoj kul 'tury i sporta, 2011;13:93-95.

111. Chueva OO. Dependence of mutual understanding in a team of beach volleyball players on their individual psychological characteristics. Sportivnyj psikholog, 2010;1(19):76-78.

112. Rozhnov AA, Efimov AI. Peculiarities of application of beach volleyball methods in the course of university students' physical education. Izvestiia Tul'skogo gosudarstvennogo universiteta. Fizicheskaia kul 'tura. Sport, 2017;1:91-96.

113. Smirnov VN. Open classroom in beach volleyball as a method of physical self-perfection of first-year students. Teoriia i praktika fizicheskoj kul 'tury, 2014;2:31-33.

114. Maaev KhK. Final results of beach volleyball term studies. Kul'tura fizicheskaia i zdorov'e, 2014;3(50):32-35.

115. Nikolenko RN, Kostiukov VV, Kostiukova ON, Maaev KhK, Dashaev KA. Usage of beach volleyball means in physical education of students and schoolchildren. Kul tura fizicheskaia i zdorov'e, 2011;3:14-17.

116. Abramov SA. Beach volleyball at the physical student's university. Aktual'nye nauchnye issledovaniia v sovremennom mire, 2020;4-4(60):7-11.

117. Kurilova VI, Red'ko SIu, Shatirko AIu. Peculiarities of development of speed qualities in senior grade students of private school sports sections in volleyball. Aktual'nye nauchnye issledovaniia $v$ sovremennom mire, 2020;113(67):67-71.

118. Bobkov M, Madiyeva G, Ongarbaeva D. Problems of modern volleyball in Kazakhstan and ways to solve them. Teoriia i metodika fizicheskoj kul'tury, 2020:140-4. https://doi.org/10.48114/2306-5540_2020_4_140

119. Rimavi AIA, Reshetniak MV, Kostyukov VV. Results of passing the norms of the 5th stage of the RLD complex by high school students. Mezhegodnaj otchetnaj nauchnaj konferencii aspirantov $i$ soiskatelej Kubanskogo gosudarstvennogo universiteta fizicheskoj kul'tury, sporta $i$ turizma, 2018;1:131-135. 


\section{Information about the authors:}

Sergii lermakov; Doctor of Pedagogical Sciences, Professor; http://orcid.org/0000-0002-5039-4517; sportart@gmail.com; Department of Sports, Gdansk University of Physical Education and Sport; Gdansk, Poland.

Tetiana Yermakova; (Corresponding Author); Doctor of Pedagogical Sciences, Professor; https://orcid.org/0000-0002-30810229; yermakova2015@gmail.com; Department of Pedagogy, Kharkiv State Academy of Design and Arts; Kharkiv, Ukraine.

Krzysztof Wnorowski; PhD; https://orcid.org/0000-0001-5505-7985; krzysztof.wnorowski@awf.gda.pl; Department of Sports, Gdansk University of Physical Education and Sport; Gdansk, Poland.

Abdelkrim Bensbaa; PhD. Physical Education and Sport, Scientific researcher; https://orcid.org/0000-0002-0931-1847; benleone@gmail.com; Military Center of Sport Training; Abu Dhabi, United Arab Emirates.

\section{Cite this article as:}

lermakov S, Yermakova T, Wnorowski K, Bensbaa A. Beach volleyball athlete training trends of Russian-language scientific resources: a systematic review. Physical Education of Students, 2021;25(5):319-338.

https://doi.org/10.15561/20755279.2021.0508

This is an Open Access article distributed under the terms of the Creative Commons Attribution License, which permits unrestricted use, distribution, and reproduction in any medium, provided the original work is properly cited http://creativecommons.org/licenses/by/4.0/deed.en

Received: 09.09.2021

Accepted: 25.10.2021; Published: 30.10.2021 